\title{
Leucocytosis as a specific risk predictor after abdominal aortic aneurysm open repair
}

\section{Leukocytoza jako specyficzny czynnik wczesnego ostrzegania o zgonie u chorych operowanych na otwarto z powodu tętniaka aorty brzusznej}

\author{
Arkadiusz Kazimierczak, Paweł Szumiłowicz, Ireneusz Wiernicki, Piotr Gutowski, Rabih Samad, Halina Kupicz, \\ Marcin Śledź, Anita Rybicka
}

Klinika Chirurgii Naczyniowej, Ogólnej i Angiologii Pomorskiego Uniwersytetu Medycznego w Szczecinie al. Powstańców Wlkp. 72, 70-111 Szczecin

Kierownik: prof. dr hab. n. med. Piotr Gutowski

\section{SUMMARY}

Introduction: Prediction of early death in abdominal aortic aneurysm - open repair is widely described. There is no superiority of any risk stratification tool. Some of the risk calculators are quite accurate, but very complicated (e.g. P-POSSUM, V-POSSUM). Some are simpler but never used in vascular surgery (e.g. ECOG). Therefore, only leucocytosis itself appears to be an independent and highly specific factor in prediction of early death prior to surgery. This might be used as an early warning factor raising surgeons' attention, especially in centers not using any risk calculators on a regular basis.

The aim of this study was to comparison of commonly used early death prediction calculators for abdominal aortic aneurysm - open repair. We took into account the following scales: Glasgow Aneurysm Score (GAS), V-POSSUM, Eagle score, American Society of Anesthesia Score, ECOG, Goldman/Detsky. However, we also have been looking for independent risk factors of early postoperative death.
Material and methods: Retrospective analysis of 79 patients who underwent elective open repair of abdominal aortic aneurysm over 3 years (2011-2013 Szczecin, Poland). We have excluded patients treated due to ruptured aneurysms and with the use of a stentgraft. Receiver operating curve analysis was used to asses all prediction abilities.

Results: We noted 6 deaths (7.59\%). Receiver operating curve analysis confirms good prediction force for V-POSSUM ( $p=0.0001$, criterion over $1.9 \%$ ) and GAS ( $p=0.0109$, criterion over 73 pt.). Areas under curve are respectively 0.806 and 0.743 . However, leucocytosis itself over $10 \mathrm{~T} / \mathrm{L}$ was the most specific (over 88\%) risk factor in early death prediction $(\mathrm{p}<0.0001)$.

Conclusion: V-POSSUM and GAS are suitable risk calculators for abdominal aortic aneurysm - open repair. Leucocytosis discovered prior to the surgery is a highly specific early death predictor.

Key words: abdominal aortic aneurysm open repair, early mortality, risk factors, risk score, V-POSSUM Score.

\section{STRESZCZENIE}

Wstęp: Prognozowanie ryzyka zgonu w leczeniu tętniaka aorty brzusznej jest zagadnieniem szeroko opisanym. Żadna ze znanych skal nie ma istotnej przewagi nad pozostałymi, jednakże niektóre są dokładniejsze (jak skale P-POSSUM, V-POSSUM), choć są zarazem bardziej skomplikowane, a ich użycie jest czasochłonne. Istnieją proste skale (skala Eagle, Glasgow Aneurysm Score - GAS) oraz takie, których nie stosowano jeszcze w chirurgii naczyniowej (skala sprawności wg Eastern Cooperative Oncology Group - ECOG). Okazuje się też, że leukocytoza jest wysoce specyficznym czynnikiem ryzyka zgonu wczesnego niezależnie od innych parametrów, co można wykorzystać jako czynnik wczesnego ostrzegania w ośrodkach niestosujących standardowo kalkulacji ryzyka zgonu wczesnego.

Celem pracy była analiza skuteczności powszechnie stosowanych skal ryzyka (GAS, V-POSSUM, skala Eagle, skala Amerykańskiego Towarzystwa Anestezjologicznego, ECOG, skala Goldmana) stosowanych przy leczeniu tętniaka aorty brzusznej na otwarto. Poszukiwano też niezależnych czynników rokowniczych. Materiał i metody: Retrospektywna analiza obejmowała 79 chorych operowanych metodą tradycyjną w ciągu 3 lat (2011-2013).
Z analizy wykluczono chorych operowanych z powodu pękniętego tętniaka aorty brzusznej oraz leczonych endowaskularnie. W analizie statystycznej wykorzystano testy ROC (receiver operating curve) do oceny zdolności predykcyjnych badanych testów.

Wyniki: W badanej grupie odnotowano 6 zgonów (7,59\%). Stwierdzono dobre właściwości predykcyjne skal V-POSSUM ( $\mathrm{p}=0,0001$, punkt odcięcia powyżej 1,9 pkt) i GAS ( $\mathrm{p}=0,0109$, punkt odcięcia powyżej 73 pkt). Wartości pola po krzywą w analizie ROC wynoszą dla wyżej wymienionych skal odpowiednio 0,806 i 0,743. Leukocy toza przekraczająca $10 \mathrm{~T} / \mathrm{L}$ stanowiła niezależny czynnik związany z istotnie wyższym odsetkiem zgonów wczesnych ( $p=0,0001)$ charakteryzujący się najwyższą specyficznością (powyżej 88\%).

Wniosek: Skale V-POSSUM i GAS są przydatne do przewidywania ryzyka zgonu po operacji tętniaka aorty brzusznej metodą na otwarto, ale leukocytoza wykryta przed operacją jest niezależnym i wysoce specyficznym czynnikiem ryzyka zgonu wczesnego. Słowa kluczowe: otwarta operacja tętniaka aorty brzusznej, zgon wczesny, czynniki ryzyka, kalkulator ryzyka, skala V-POSSUM. 


\section{INTRODUCTION}

The risks of the treatment of abdominal aortic aneurysm (AAA) depend on the type of surgery (open repair - OR / endovascular aneurysm repair - EVAR), the surgeon's skills/experience, and the patient's condition. Disregarding the first two factors, which we can influence, only the patient's condition independently affects the results of surgery. There are many ways to assess the patient's condition in terms of general condition and cardiovascular risk factors. Well known and suitable methods are the Glasgow Aneurysm Score (GAS), the Portsmouth - Physiological and Operative Severity Score for the enumeration of Mortality and Morbidity (P-POSSUM), the V-POSSUM (named after the vascular variant), Eagle Score, Leiden Score, Vanzetto Score, SVS Score, and the also popular American Society of Anesthesia Score (ASA) or Goldman/ Detsky Score $[1,2,3,4,5,6,7]$. Moreover, using other calculators, like ECOG (Eastern Cooperative Oncology Group) might be a very interesting option. The utility of this scale is well proven in haematology. However, patient mobility, assessed on this scale, also influences every surgical intervention [4]. The advantage of ECOG based on its simplicity remains contrary to the other calculation, e.g.: P-POSSUM and V-POSSUM already successfully used in vascular surgery. The difficulty of the use of such complicated tools is a reason for its limited exploitation in vascular centres. The technological revolution in vascular surgery triggers continuous efforts for better quality control. Better tools assessing early results are part of that, and are demanded by insurance companies in the reality of the rising costs of treatment. In this way, continuous research for the most effective and specific risk calculation remains an important topic in AAA treatment. This explains our endeavour to compare the variety of different options (some of them never used in vascular surgery).

We wish to compare the accuracy of some commonly used risk calculators, and to look for independent preoperative risk factors in the group of patients treated due to aortic aneurysm with elective open repair.

\section{MATERIAL AND METHODS}

79 patients with elective open repair of AAA in the Vascular Surgery Department of Pomeranian Medical University in Szczecin (Poland) over 3 years (2011-2013). There were 66 males and 13 females excluded from EVAR due to difficult aneurysm anatomy or other independent reasons. We also excluded patients treated due to ruptured AAA but not symptomatic patients (10) as far as admitted electively from the waiting list. There were 4 cases with inflamed AAA (appearing during surgery).

Retrospective analysis data collected in Electronic System of Data Maintenance - Infomedica, Asseco, Warsaw, Poland, University Hospital № 2 in Szczecin, Poland. We took into account the following qualitative factors: age, body mass, ions, morphology (including white blood count (WBC) in T/L, initial haemoglobin concentration in $\mathrm{mg} / \mathrm{dL}$, and platelet

\section{WSTĘP}

Prognozowanie ryzyka zgonu w przypadkach planowych operacji tętniaka aorty brzusznej (AAA) metodą na otwarto (OR) jest dobrze znanym problemem. Wciąż dokonywane są aktualizacje skuteczności skal ryzyka ze względu na rozwój mniej inwazyjnych endowaskularnych technik leczenia (EVAR). Najczęściej stosowanymi kalkulatorami ryzyka są w tych przypadkach Glasgow Aneurysm Score (GAS), Portsmouth - Physiologic and Operative Severity Score for the enUmeration of Mortality and Morbidity (P-POSSUM, V-POSSUM), a także skale Eagle, Leiden, Vanzetto i SVS. Popularne są również skala Amerykańskiego Towarzystwa Anestezjologicznego (ASA), skala sprawności wg Eastern Cooperative Oncology Group (ECOG) oraz skala Goldmana $[1,2,3,4,5,6,7]$. Ich skuteczność jest oceniana bardzo różnie, co wynika chociażby z tego, że skale te biorą pod uwagę różnorodne czynniki ryzyka oraz przypisują im odmienną siłę oddziaływania. Wobec tego, że przewidywanie ryzyka zgonu spełnia bardzo istotną rolę w kwalifikacji do odpowiedniego sposobu leczenia, szczególnie ważny wydaje się dobór właściwego kalkulatora ryzyka oraz kontynuowanie poszukiwań innych niezależnych czynników ryzyka zgonu wczesnego u chorych leczonych z powodu AAA.

Celem pracy była analiza skuteczności powszechnie stosowanych skal ryzyka oraz poszukiwanie niezależnych przedoperacyjnych czynników ryzyka zgonu wczesnego w grupie chorych operowanych planowo z powodu tętniaka aorty brzusznej.

\section{MATERIA I I METODY}

Materiał stanowiło 79 chorych operowanych metodą tradycyjną w Klinice Chirurgii Naczyniowej, Ogólnej i Angiologii Pomorskiego Uniwersytetu Medycznego w Szczecinie (PUM) w ciągu 3 lat (2011-2013). W grupie było 66 mężczyzn i 13 kobiet. Z analizy wykluczono chorych operowanych z powodu pękniętego tętniaka aorty brzusznej. W całej grupie 28 chorych miało objawowego tętniaka. U 4 chorych stwierdzono tętniaka zapalnego.

Metodą badań była retrospektywna analiza danych gromadzonych w szpitalnej komputerowej bazie danych poszerzonej o formularze dedykowane dla chirurgii naczyniowej. Analizie poddano szereg zmiennych mierzalnych, w tym: wiek, wagę, jonogram, morfologię, kreatyninę/GFR (glomerular filtration rate), czas hospitalizacji. Badano również wartość predykcyjną powszechnie stosowanych skal ryzyka, w tym ASA, ECOG, skali Eagle, GAS, skali Goldmana, V-POSSUM. Wśród zmiennych policzalnych uwzględniono płeć oraz choroby współistniejące, takie jak utrwalone migotanie, chorobę wrzodową żołądka i dwunastnicy w wywiadzie, obturacyjną chorobę płuc, nadciśnienie tętnicze, cukrzycę, chorobę nowotworową w wywiadzie, frakcję wyrzutową poniżej 30\%, przewlekłą niewydolność krążenia, chorobę wieńcową, przebyty zawał serca, przebyty epizod naczyniowo-mózgowy, palenie oraz typ tętniaka (objawowy/zapalny).

Dane poddano analizie statystycznej przy użyciu programu Statistica PL. We wstępnej analizie porównywano odsetek 
count in G/L, creatinine/GFR (Glomerular Filtration Rate in $\mathrm{mL} / \mathrm{min} / 1.73 \mathrm{msq}$ ) independently of the risk assessing scores, including: ASA, ECOG, Eagle, GAS, Goldman/Detsky and V-POSSUM. Among quantitative factors we examined the following factors: continuous atrial fibrillation (AF), chronic obstructive pulmonary disease, arterial hypertension, diabetes mellitus, cancer, low (below 30\%) ejection fraction (EF\%), chronic circulatory failure, coronary artery disease, myocardial infarct, cerebro-vascular accident/stroke, smoking, and type of aneurysm (asymptomatic/symptomatic/inflamed).

For statistical analysis we used Statistica 0.5 and MedCalc 2012 Software. To compare quantitative variables we used the Fisher exact test and the U Mann-Whitney test for qualitative variables. Wilk's lambda test was finally performed to confirm independent risk factors in discriminate multifactor analysis. Comparison of predictive force and accuracy between risk factors (risk scores and suspected independent risk factors) was performed based on the Receiver Operating Curve (ROC), the calculated area under curve (AUC), and criteria, for sensitivity and specificity. Statistically significant differences were considered for $\mathrm{p}$-value less than 0.05 .

\section{RESULTS}

We noted 6 deaths during the first 30 days after surgery (7.6\%). Differences between groups of survivals and death patients observed within 30 days after open repair of AAA according to all compared variables are presented in Table 1.

Among quantitative variables none has shown a significant influence on the death rate. However, there were two borderline factors, i.e. the presence of continuous atrial fibrillation and EF\% below 30\%. Qualitative variables show significant differences between the groups (death/survivals) respectively in age, haemoglobin concentration and WBC, GAS and V-POSSUM Scores. See Table 1.

Discriminate analysis of those factors, performed to exclude autocorrelation, verified only two variables. Respectively, WBC (Wilk's lambda 0.9263, F = 0.817, $\mathrm{p}=0.000166$ ) and V-POSSUM Score (Wilk's lambda - 0.802, $F=4.22, \mathrm{p}=0.04357$ ).

In the next step ROC analysis was utilized to assess the accuracy and predictive power of all the considered scores. However, we also took into account WBC as an independent factor due to its positive discriminate verification. The criterion for WBC appears to be over $10 \mathrm{~T} / \mathrm{L}$. See Table 2.

Leucocytosis appears to be the most specific predictor of early death. However, its predictive force does not achieve statistical significance as well as the ECOG, Eagle and Goldman scales.

\section{DISCUSSION}

$5 \%$ is the maximum acceptable death rate after open repair of AAA. Such a cut off level is estimated based on observed risk of death due to aneurysm rupture during one year [8]. This confirmed why death risk stratification is important before surgery, zgonów w grupach z poszczególnymi czynnikami przy użyciu testu $\chi^{2}$. Zmienne mierzalne (parametry biochemiczne i wartości skal ryzyka) porównano między grupami testem U Manna-Whitneya ze względu na ich nienormalny rozkład. Po wstępnym wyodrębnieniu czynników częściej współistniejących ze zgonem wczesnym przeprowadzono analizę dyskryminacyjną (Wilks' lambda), usuwając czynniki korelujące ze sobą bardziej niż ze zgonem wczesnym, celem stworzenia i zweryfikowania modelu statystycznego wyjaśniającego obserwowane zależności. Porównanie siły predykcyjnej ostatecznie wyodrębnionych czynników przeprowadzono metodą ROC (receiver operating curve) z oceną pola pod krzywą (area under curve - AUC) oraz z określeniem punktów odcięcia, wraz z ich czułością i specyficznością. Za istotne statystycznie uznawano zależności przy p < 0,05.

\section{WYNIKI}

W badanej grupie odnotowano 6 zgonów (7,6\%). Spośród zmiennych policzalnych żadna nie wykazała istotnej różnicy liczebności pomiędzy grupą pacjentów, którzy zmarli do 30 dni, a grupą pacjentów, którzy przeżyli. Wyjątek stanowią dwie zmienne, dla których obserwowano graniczne wartości p. Były to utrwalone migotanie przedsionków i frakcja wyrzutowa poniżej 30\%. Spośród zmiennych mierzalnych istotne różnice między badanymi grupami dotyczyły tylko wieku, poziomu hemoglobiny (Hb) oraz białych krwinek (WBC), a także wartości skal GAS i V-POSSUM przy przyjęciu. Wyniki przedstawiono w tabeli 1.

Wszystkie powyższe czynniki, które wyodrębniono w analizie jednoczynnikowej, były podejrzewane o związek ze zgonem wczesnym. W celu wyeliminowania wzajemnych autokorelacji zmienne te poddano analizie dyskryminacyjnej. Weryfikację pozytywnie przeszły tylko dwie zmienne: keukocytoza (Wilks Lambda $=0,9263, \mathrm{~F}=0,817, \mathrm{p}=0,000166$ ) oraz wartość skali V-POSSUM (Wilks Lambda = 0,802, F = 4,22, p = 0,04357).

Do określenia zdolności predykcyjnych użyto analizy ROC dla wszystkich skal. Dodatkowo uwzględniono poziom leukocy tów, traktując go jako niezależny czynnik predykcyjny zgonu w związku z powyżej przytoczonymi wynikami analizy dyskryminacyjnej (dla WBC punktem odcięcia była wartość powyżej $10 \mathrm{~T} / \mathrm{L}$ (tab. 2).

Okazało się, że jedynie skale GAS i V-POSSUM wykazały zdolności predykcyjne w wykrywaniu zgonu wczesnego ( $\mathrm{p}<0,05)$, przy czym skala P-POSSUM miała najlepsze właściwości (najwyższe pole pod krzywą, AUC). Poziom WBC >10 T/L nie był wystarczająco czułym, ale za to okazał się najbardziej specyficznym predyktorem wczesnego zgonu. Miał przy tym znacznie lepsze wartości predykcyjne niż pozostałe skale ECOG, Eagle i Goldmana.

\section{OMÓWIENIE I DYSKUSJA}

Powszechnie akceptowalne ryzyko zgonu w planowej operacji tętniaka aorty brzusznej nie powinno przekraczać 3-5\% [8]. 
TABLE 1. Differences between survival and death after abdominal aortic aneurysm open repair

TABELA 1. Różnice pomiędzy chorymi przeżywającymi a umierającymi w trakcie operacyjnego leczenia z powodu tętniaka aorty brzusznej

\begin{tabular}{|c|c|c|c|}
\hline \multirow{2}{*}{$\begin{array}{l}\text { Qualitative variables } \\
\text { Zmienne mierzalne }\end{array}$} & $\begin{array}{l}\text { Died within } 30 \text { days (6) } \\
\text { Zgon do } 30 \text { dni (6) }\end{array}$ & $\begin{array}{l}\text { Survival (73) } \\
\text { Przeżycie (73) }\end{array}$ & p \\
\hline & \multicolumn{2}{|c|}{ mean value / średnia wartość } & \\
\hline GAS (pkt / pt.) & 86.50 & 75.10 & 0.0375 \\
\hline ASA (class) & 3.43 & 2.65 & NS (0.067) \\
\hline Goldman Score (pt.) / Skala Goldmana (pkt) & 22.57 & 22.57 & NS \\
\hline ECOG (pkt / pt.) & 2.43 & 2.29 & NS \\
\hline WBC (T/L) & 15.6 & 8 & 0.00078 \\
\hline Haemoglobin (g/dL) / Hemoglobina (g/dL) & 9.98 & 13.38 & NS \\
\hline Age (years) / Wiek (lata) & 77.80 & 68.70 & 0.015 \\
\hline Body mass (kg) / Masa ciała (kg) & 74.75 & 79.66 & NS \\
\hline $\mathrm{K}(\mathrm{mmol} / \mathrm{L})$ & 13.93 & 4.56 & NS \\
\hline GFR (mL/min/1.73 msq) & 63.78 & 72.27 & NS \\
\hline Qualitative variables / Zmienne mierzalne & $\mathrm{n}(\%)$ & $\mathrm{n}(\%)$ & \\
\hline Male sex $(n=66) /$ Płeć męska $(n=66)$ & $5(83.33 \%)$ & $61(83.56 \%)$ & NS \\
\hline $\begin{array}{l}\text { Continuous atrial fibrillation }(n=7) \\
\text { Utrwalone migotanie przedsionków }(n=7)\end{array}$ & $2(33.33 \%)$ & $5(6.85 \%)$ & NS (0.08) \\
\hline $\begin{array}{l}\text { Symptomatic abdominal aortic aneurysm }(n=10) \\
\text { Objawowy tętniak aorty brzusznej }(n=10)\end{array}$ & $2(33.33 \%)$ & $8(10.96 \%)$ & NS \\
\hline $\begin{array}{l}\text { Inflammatory abdominal aortic aneurysm }(n=4) \\
\text { Zapalny tętniak aorty brzusznej }(n=4)\end{array}$ & $1(16.67 \%)$ & $3(4.11 \%)$ & NS \\
\hline $\begin{array}{l}\text { Ejection fraction below } 30 \%(n=3) \\
\text { Frakcja wyrzutowa poniżej } 30 \%(n=3)\end{array}$ & $1(16.67 \%)$ & $2(2.74 \%)$ & NS (0.052) \\
\hline $\begin{array}{l}\text { Chronic circulatory failure }(n=3) \\
\text { Przewlekła niewydolność krążenia }(n=3)\end{array}$ & $0(0 \%)$ & $3(4.11 \%)$ & NS \\
\hline $\begin{array}{l}\text { Chronic obturatory pulmonary disease }(n=15) \\
\text { Obturacyjna choroba płuc }(n=15)\end{array}$ & $1(16.67 \%)$ & $14(18.18 \%)$ & NS \\
\hline Arterial hypertension $(n=64) /$ Nadciśnienie tętnicze $(n=64)$ & $5(83.33 \%)$ & $59(80.82 \%)$ & NS \\
\hline Diabetes $(n=7) /$ Cukrzyca $(n=7)$ & $0(0 \%)$ & $7(9.59 \%)$ & NS \\
\hline Cancer $(n=7) / \operatorname{Rak}(n=7)$ & $0(0 \%)$ & $7(9.59 \%)$ & NS \\
\hline $\begin{array}{l}\text { Coronary artery disease }(n=30) \\
\text { Choroba wieńcowa }(n=30)\end{array}$ & $5(83.33 \%)$ & $25(34.25 \%)$ & NS \\
\hline Myocardial infarct $(n=17) /$ Zawał serca $(n=17)$ & $2(33.33 \%)$ & $15(20.55 \%)$ & NS \\
\hline $\begin{array}{l}\text { Cerebrovascular accident/stroke }(\mathrm{n}=9) \\
\text { Epizod naczyniowo-mózgowy }(\mathrm{n}=9)\end{array}$ & $1(16.67 \%)$ & $8(10.96 \%)$ & NS \\
\hline Smoking $(n=17) /$ Palenie $(n=17)$ & $1(16.67 \%)$ & $16(21.92 \%)$ & NS \\
\hline
\end{tabular}

being a basis for appropriate qualification for surgery. Higher risk patients (death rate over $5 \%$ if treated in OR) should be primary qualified for EVAR, because this is a much less invasive procedure. This is reflected in appropriate risk calculators (V-POSSUM and P-POSSUM, calculating the risk of treatment due to ruptured aortic aneurysm). In our department we use the V-POSSUM score on a regular basis. If the risk is higher than $5 \%$, the patient is qualified for appropriate stent-graft implantation, depending on aneurysm anatomy. According to our recent research, $5 \%$ become the borderline risk which should qualify the patient for EVAR in our department. A personalized calculation of death and complication rate, shown in percent, is more understandable for the patients, and has become an important part of our consent form.
Dlatego istotne jest umiejętne wyjściowe oszacowanie ryzyka zgonu w celu wybrania odpowiedniej techniki leczenia chorego. W przypadku obciążenia chorobami współistniejącymi istnieje możliwość leczenia mniej inwazyjnego, np. technikami endowaskularnymi. W Klinice Chirurgii Naczyniowej, Ogólnej i Angiologii PUM stosuje się tę strategię, kwalifikując do EVAR chorych z ryzykiem zgonu przekraczającym $5 \%$ przy operacji na otwarto. Szacowanie ryzyka w przypadku leczenia tętniaków aorty brzusznej jest bardzo dobrze opracowane. Uważa się, że dobre zdolności predykcyjne wykazują skale: Eagle, GAS, Leiden, Vanzetto, P-POSSUM, V-POSSUM, SVS i inne [1, 2, 3]. Obserwowany odsetek zgonów w grupie chorych leczonych na otwarto nie odbiega od raportowanego w piśmiennictwie. Dlatego grupa ta stanowi wiarygodną bazę dla wzajemnego 
TABLE 2. Comparison of the prediction tools

TABELA 2. Porównanie skal użytych do przewidywania ryzyka zgonu wczesnego

\begin{tabular}{|c|c|c|c|c|c|c|}
\hline $\begin{array}{l}\text { Variable } \\
\text { Zmienna }\end{array}$ & $\begin{array}{l}\text { Area under curve } \\
\text { Pole pod krzywą }\end{array}$ & $p$ & $95 \% \mathrm{Cl}$ & $\begin{array}{c}\text { Criterion } \\
\text { Punkt odcięcia }\end{array}$ & $\begin{array}{l}\text { Sensivity } \\
\text { Czułość }\end{array}$ & $\begin{array}{c}\text { Specificity } \\
\text { Specyficzność }\end{array}$ \\
\hline V-POSSUM & 0.806 & 0.0001 & $0.697-0.889$ & $>1.9$ & $100 \%$ & $55.9 \%$ \\
\hline GAS & 0.743 & 0.0109 & $0.627-0.838$ & $>73$ & $100 \%$ & $49.3 \%$ \\
\hline WBC & 0.720 & 0.1610 & $0.603-0.819$ & $>10$ & $66.7 \%$ & $88.2 \%$ \\
\hline ECOG & 0.697 & 0.6906 & $0.578-0.799$ & $>2$ & $66.7 \%$ & $74.0 \%$ \\
\hline Eagle & 0.652 & 0.6500 & $0.531-0.760$ & $>2$ & $67.9 \%$ & $54.2 \%$ \\
\hline $\begin{array}{l}\text { Goldman Score } \\
\text { Skala Goldmana }\end{array}$ & 0.583 & 0.5818 & $0.462-0.698$ & $>10$ & $66.7 \%$ & $57.4 \%$ \\
\hline
\end{tabular}

Death risk assessment in OR-AAA is widely reported in the literature. It is also modified following new surgical technologies (EVAR/TEVAR etc.). Appropriate accuracy is proved for the following scores: Eagle, GAS, Leiden, and modified Leiden, Vanzetto, P-POSSUM, V-POSSUM and SVS $[1,2,3]$. The death rate we noticed in our study is acceptable and comparable to that reported from other centres $[1,5]$. In this way our group is representative, comparing the variety of different scores predicting early death (up to 30 days) after surgery.

Receiving operating curve analysis (results shown in Table 2) confirmed the accuracy of GAS and V-POSSUM scores in the prediction of early death ( $\mathrm{p}<0.05)$. Moreover, V-POSSUM shows the highest sensitivity in prediction (the highest AUC). Among all the examined scores the presence of leucocytosis (WBC over $10 \mathrm{~T} / \mathrm{L}$ ) itself is especially interesting, and shows the highest specificity and much better predictive force (higher AUC) than ECOG, Eagle and GOLDMAN/Detsky Scores. Unfortunately, leucocytosis is not sensitive enough ( $p$-value over 0.05) to become an independent and only risk predictor. However, it might be recognised as an early warning factor.

Eastern Cooperative Oncology Group was primary dedicated to oncology/haematology to assess the general condition, mobility and quality of life [4]. Their accuracy was well proved in the matter of survival rate after aggressive treatment (including chemotherapy). It seems to be a promising tool in extensive or high risk vascular surgery as well. It is well known that patient mobility and general condition influences the treatment results in critical limb ischemia. It seems to be an important factor in rehabilitation after extensive abdominal surgery. However, no score system currently used for risk prediction in AAA surgery takes this into account. Unfortunately, ECOG appears useless in early death stratification after OR (AAA) in our study. However, their accuracy in the prediction of early death after open surgery is higher than Eagle or Goldman/Detsky Scores.

Contrary to ECOG, the Eagle Score was created to assess the cardiovascular risk immediately after AAA-OR [5]. This is a very simple and user-friendly calculator. Unfortunately, we cannot confirm its usefulness in our group, as with the Goldman/Detsky Score. Those scores was primary dedicated to cardiovascular risk assessment after general surgery (different from cardiothoracic), including vascular surgery [7]. A lack of predictive power for the ASA scale is also surprising, as it is the most commonly used score system in anaesthesiology [6]. porównania kilku narzędzi predykcyjnych oraz stanowi podstawę do poszukiwania innych silnych i niezależnych czynników przewidujących zgon chorego w okresie do 30 dni od operacji.

Wyniki zestawione w tabeli 2 stanowią wstępne podsumowanie własności predykcyjnych kilku popularnie stosowanych skal ryzyka. Wśród nich jedynie skale V-POSSUM i GAS okazały się być przydatne. Skale ECOG, Eagle, ASA i Goldmana nie przewidywały zgonu z wystarczającą czułością.

Stan ogólny chorego może pełnić istotną rolę w kwalifikacji do leczenia inwazyjnego. Żadna ze skal oceniających ryzyko zgonu wczesnego nie bierze jednak tego parametru pod uwagę. Dlatego też obiecująca wydawała się ocena badanej grupy w kontekście skali ECOG, która pierwotnie była dedykowana dla chorych onkologicznych. Jest to skala sprawności, za pomocą której można określić stan ogólny i jakość życia pacjenta z chorobą nowotworową albo inną przewlekłą lub ciężką [4]. Okazało się jednak, że jej wskazania nie mają wartości predykcyjnych u chorych operowanych z powodu AAA.

W przeciwieństwie do skali ECOG, skala Eagle była tworzona do oceny ryzyka sercowo-naczyniowego dla chorych operowanych z powodu tętniaka aorty brzusznej [5]. Jest bardzo prostą i przez to użyteczna skalą, ale niestety w badanym materiale zupełnie się nie sprawdziła. Podobnie zresztą jak skala Goldmana, za pomocą której również ocenia się ryzyko powikłań sercowo-naczyniowych u chorych operowanych z powodów innych niż kardiochirurgiczne [7]. Dziwi też fakt braku praktycznej użyteczności najpowszechniej stosowanej w każdej dziedzinie chirurgii i anestezjologii skali ASA [6].

Pozostały więc tylko V-POSSUM i GAS, z których ta pierwsza wykazała się wyższą czułością i jako jedyna pozytywnie przeszła weryfikację w analizie dyskryminacyjnej. Skala V-POSSUM jest odmianą skali P-POSSUM. Działa ona w oparciu o identyczny logarytm, ale dodatkowo podaje wynik dla leczenia pękniętego tętniaka. Jest to modyfikacja wymuszona odmiennym rokowaniem w grupie chorych z pękniętym tętniakiem. W związku z tym, że w badaniu własnym nie oceniano pękniętych tętniaków, wartość predykcyjna obu skal była równoważna. Badanie potwierdziło niezależną siłę predykcyjną skali V-POSSUM. Niestety jest ona znacznie bardziej skomplikowana niż GAS, ponieważ odzwierciedla obciążenie chorego chorobami współistniejącymi oraz głębokość odchyleń w licznych parametrach biochemicznych i używa logarytmicznej kalkulacji [9, 10]. Nie sposób jej zatem użyć bez odpowiedniego 
Eventually, under our consideration only two scores remain, i.e. V-POSSUM and GAS as suitable for risk assessment after OR (AAA). However, V-POSSUM appears to be the most sensitive and passes the discriminate verification, which proved its independent predictive force.

Unfortunately, V-POSSUM is much more complicated than GAS due to the variety of biochemical and physiological factors needed $[9,10]$. It is impossible to use it without any electronic support (computer software, mobile or website calculator) due to the long list of factors, e.g. blood pressure, past medical history, ECG parameters, EF\%, AF and many more. In our group the criterion for elevated death rate in V-POSSUM exceeded $1.9 \%$. However, the mean value in this group was over $9.8 \%$. Bryce et al., for example, noted about a $40 \%$ risk [11]. In contrast, the Glasgow Aneurysm Score is much simpler. Its effectiveness was also proved in OR as well as in EVAR procedures [3]. The criteria postulated in the literature for open surgery are below 75.5\%, and for EVAR over $86.5 \%$ (which proves reasonable qualification for surgery) [3]. In our study the criterion distinguishing high risk group was above $73 \mathrm{pt}$. and the mean GAS value in the death group was $86.5 \mathrm{pt}$. These are similar results compared to other centres [3]. However, Supsamutchai i wsp. noted a lower (81 pt.) value of GAS in the group of early death [12].

Following other authors, we noted the superiority of the V-POSSUM over the GAS score [11,12]. Supsamutchai et al. and Bryce et al. independently confirmed the better predictive force of P-POSSUM compared to GAS. Reported AUC value varied, respectively, from 0.681 to 0.89 for P-POSSUM and from 0.632 to 0.76 for GAS $[11,12]$. Moreover, the mean value for the death patients within 30 days were 81 pt. for GAS and $43 \%$ for the P-POSSUM Score [12].

In our opinion, the most interesting discovery related to elevated death rate was leucocytosis discovered initially on admission. Leucocytosis was qualified as WBC over $10 \mathrm{~T} / \mathrm{L}$. This criterion was independently confirmed in our statistical analysis. Leucocytosis definitely shows an independent relationship to the highest death rate, and as the risk factor was the most specific. Moreover, the presence of WBC in the P-POSSUM and V-POSSUM calculators does not reduce its value in discriminate analysis, and confirms its high predictive power. According to such findings, we cannot forget the influence of the inflammatory processes on the early results [13]. There are some reports suggesting severe inflammatory response syndrome after invasive vascular operations [14]. Some authors reported higher WBC in the group of AAA compare to the Leriche syndrome, as well as a higher mortality rate $[15,16]$. Elevated WBC (especially granulocyte count) shows a correlation with higher elastolytic activity in the serum of patients with AAA, which influences inflammatory reaction and possibly worsens the early results of surgery $[16,17]$. However, it is hard to find reports confirming the relationship of leucocytosis which elevate the risk of early death after AAA open repair. There is no doubt that leucocytosis is observed in ruptured and inflammatory aneurysms [15]. We did not exclude inflamed aneurysms from the study, simply because it was urządzenia elektronicznego przetwarzającego wprowadzone dane. Oprócz tego w skład tej skali wchodzi szereg parametrów oceniających wydolność krążenia, w tym migotanie przedsionków i upośledzoną frakcję wyrzutową. Te dwa ostatnie parametry wydawały się wykazywać zresztą wyraźną tendencję modyfikującą ryzyko zgonu wczesnego w materiale własnym. W analizowanej grupie wartość V-POSSUM wynosiła średnio ponad 9,8\% w grupie chorych zmarłych. Bryce i wsp. odnotowali w tych przypadkach ponad $40 \%$ ryzyko [11].

Glasgow Aneurysm Score jest z kolei znacznie prostszą i dobrze udokumentowaną skalą oceny ryzyka zgonu dla chorych operowanych z powodu AAA zarówno metodą otwartą, jak i endowaskularnie [3]. Punkt odcięcia dla operacji na otwarto znajduje się powyżej 75,5\%, a dla EVAR 86,5\% [3]. Jest to naturalne, ponieważ do mniej inwazyjnego leczenia kwalifikuje się chorych z większymi obciążeniami i przez to z wyższą punktacją w skali Glasgow. W materiale własnym (leczenie na otwarto) wartość punktacji Glasgow wyniosła średnio dla zgonów 86,5 pkt, a punkt odcięcia powyżej 73 pkt, co nie odbiega od obserwacji poczynionych w innych ośrodkach [3], choć Supsamutchai i wsp. notowali średnio nawet 81 pkt w skali GAS [12].

Również chorzy z niedokrwistością mieli mniejsze szanse powodzenia leczenia operacyjnego. Stwierdzono, że Hb poniżej $9 \mathrm{mg} / \mathrm{dL}$ była istotnie częściej notowana w tej grupie chorych. Może to odzwierciedlać ogólnie gorszą kondycję pacjenta. Jednak wartość Hb jest jednym z parametrów wchodzących w skład kalkulatora V-POSSUM. I jak się okazało w toku analizy dyskryminacyjnej, nie wykazuje samodzielnie niezależnego wpływu na podwyższenie ryzyka zgonu.

Ponadto w analizie własnej potwierdzono przewagę predykcyjną skali V-POSSUM nad skalą GAS, podobnie zresztą jak i inni autorzy $[11,12]$. Supsamutchai $i$ wsp., a także Bryce i wsp. ocenili niezależnie od siebie, że skala P-POSSUM (wersja nieoceniająca ryzyka leczenia pękniętego tętniaka aorty w porównaniu do V-POSSUM) lepiej przewiduje zgon niż GAS. Odpowiednie wartości AUC dla P-POSSUM i GAS wynoszą odpowiednio 0,681-0,89 i 0,632-0,76 [11,12]. Natomiast średnie wartości dla pacjentów, którzy zginęli, wynoszą 81 dla GAS i 43 dla P-POSSUM [12].

Najciekawszym odkryciem okazała się podwyższona leukocytoza stwierdzana przy przyjęciu do szpitala. Wykazywała ona niezależny i samodzielny związek z wyższym ryzykiem zgonu (mimo że jej obecność podwyższała jednocześnie szacowane ryzyko w skali V-POSSUM). Wobec stwierdzenia, że szczególnie często z ryzykiem zgonu wiązała się wartość przekraczająca 10 tys., nie można pominąć aspektu odczynu zapalnego jako czynnika ryzyka wczesnych powikłań [13]. Sugerowane jest nawet występowanie zespołu ogólnoustrojowej reakcji zapalnej po dużych operacjach naczyniowych, co nie pozostaje bez wpływu na wyniki leczenia [14]. Trudno jest jednak znaleźć doniesienia, że leukocytoza sama w sobie podnosi ryzyko zgonu wczesnego operacji AAA na otwarto. Podwyższoną leukocytozę obserwuje się częściej w tętniakach zapalnych i w przypadku tętniaka pękającego [15]. Dlatego też ten parametr, którego badanie jest łatwo dostępne 
impossible to suspect it directly on admission (it was always intraoperative recognition).

In conclusion, leucocytosis appears to be an independent and highly specific factor in the prediction of early death after open AAA repair. It is easy to check using inexpensive tests, so might be useful as an early warning factor in centres which do not use any specific risk calculating scores on a regular basis.

\section{CONCLUSIONS}

1. V-POSSUM and GAS are suitable risk calculators after abdominal aortic aneurysm open repair.

2. Leucocytosis discovered prior to surgery is a highly specific early death predictor. i niedrogie, może być pomocny w ocenie ryzyka wczesnego zgonu u chorych operowanych na otwarto z powodu tętniaka aorty brzusznej. Średnie stężenie leukocytów u pacjentów z AAA jest znacząco wyższe niż w grupie kontrolnej $(\mathrm{p}<0,001)$, jak również większa jest ich wczesna śmiertelność pooperacyjna (do $30 \mathrm{dni}$ ) w porównaniu z pacjentami operowanymi z powodu zespołu Leriche'a [16]. Podwyższona leukocytoza (granulocyty obojętnochłonne) wykazuje związek ze wzrostem aktywności elastolitycznej we krwi obwodowej pacjentów z AAA [17]. Koresponduje to z komponentem zapalnym w patogenezie i przebiegu AAA, którego nasilenie przyspiesza rozwój tętniaka i pogarsza wczesne wyniki leczenia [16, 17].

Warto podkreślić, że specyficzność leukocytozy w predykcji zgonu wczesnego jest bardzo wysoka (najwyższa spośród analizowanych parametrów). Zatem wystąpienie leukocytozy przed operacją można rozważać jako czynnik wczesnego ostrzegania szczególnie w ośrodkach nie stosujących standardowo kalkulacji ryzyka zgonu wczesnego.

\section{WNIOSKI}

1. Do przewidywania zgonu wczesnego w leczeniu AAA metodą otwartą dobrze nadają się skale V-POSSUM oraz GAS.

2. Leukocytoza jest wysoce specyficznym czynnikiem ryzyka zgonu wczesnego w leczeniu operacyjnym z powodu tętniaka aorty brzusznej.

\section{REFERENCES / PIŚMIENNICTWO}

1. Nesi F., Leo E., Biancari F., Bartolucci R., Rainio P., Satta J. et al.: Preoperative risk stratification in patients undergoing elective infrarenal aortic aneurysm surgery: evaluation of five risk scoring methods. Eur J Vasc Endovasc Surg. 2004, 28 (1), 52-58.

2. Barnes M., Boult M., Maddern G., Fitridge G.: A model to predict outcomes for endovascular aneurysm repair using preoperative variables. Eur J Vasc Endovasc Surg. 2008, 35 (5), 571-579.

3. Baas A., Janssen K., Prinssen M., Buskens E., Blankensteijn J.: The Glasgow Aneurysm Score as a tool to predict 30-day and 2-year mortality in the patients from the Dutch Randomized Endovascular Aneurysm Management trial. J Vasc Surg. 2008, 47 (2), 277-281.

4. Oken M.M., Creech R.H., Tormey D.C., Horton J., Davis T.E., McFadden E.T. et al.: Toxicity and response criteria of the eastern cooperative oncology group. Am J Clin Oncol. 1982, 5 (6), 649-655.

5. Italien G., Paul D.S., Hendel R.C., Leppo J.A., Cohen M.C., Fleisher L.A. et al.: Development and validation of a Baysian model for perioperative cardiac risk assessment in a cohort of 1,081 vascular surgical candidates. J Am Coll Cardiol. 1996, 27 (4), 779-786.

6. Little J.: Consistency of ASA grading. Anaesthesia. 1995, 50 (7), 658-659.

7. Goldman L., Caldera D.L., Nussbaum S.R., Sputhwick F.S., Krogstad D., Murray B. et al:: Multifactorial index of cardiac risk in noncardiac surgical procedures. N Engl J Med. 1977, 297 (16), 845-850.

8. Nowygrod R., Egorova N., Greco G., Anderson P., Gelijns A., Moskowitz A. et al.: Trends, complications, and mortality in peripheral vascular surgery. J Vasc Surg. 2006, 43 (2), 205-216

9. Muzolf J., Onichimowski D., Podlińska I.: Preoperative risk evaluation in cardiac patients scheduled for vascular surgery. Anest Intens Ter. 2008, 40 (2), 103-107.

10. Wolters U., Mannheim S., Wassmer G., Brunkwall J.: What is the value of available risk-scores in predicting postoperative complications after aorto-iliac surgery? A prospective non randomized study. J Cardiovasc Surg (Torino). 2006, 47 (2), 177-185.

11. Bryce G., Payne C., Gibson S., Kingsmore D., Byrne D., Delles C.: Risk stratification scores in elective open abdominal aortic aneurysm repair: are they suitable for preoperative decision making? Eur J Vasc Endovasc Surg. 2012, 44 (1), 55-61.

12. Supsamutchai C., Wilasrusmee C., Lertsithichai P., Proprom N., Kittur D.: Comparison of risk-scoring systems in predicting hospital mortality after abdominal aortic aneurysm repair. Int J Angiol. 2008, 17 (4), 181-185.

13. Monahan T.S., Owens C.D.: Risk factors for lower-extremity vein graft failure. Semin Vasc Surg. 2009, 22 (4), 216-226.

14. Hassen T.A., Pearson S., Cowled P.A., Fitridge R.A.: Preoperative nutritional status predicts the severity of the systemic inflammatory response syndrome (SIRS) following major vascular surgery. Eur J Vasc Endovasc Surg. 2007, 33 (6), 696-702.

15. Hellmann D., Grand D., Freischlag J.: Inflammatory abdominal aortic aneurysm JAMA. 2007, 297 (4), 395-400.

16. Cannon D.J., Read R.C.: Blood elastolytic activity in patients with aortic aneurysm. Ann Thorac Surg. 1982, 34 (1), 10-15.

17. Wiernicki I., Gutowski P., Ciechanowski K., Millo B., Wieczorek P., Cnotliwy M. et al:: Abdominal aortic aneurysm: association between haptoglobin phenotypes, elastase activity, and neutrophil count in the peripheral blood. Vasc Surg. 2001, 35 (5), 345-350. 